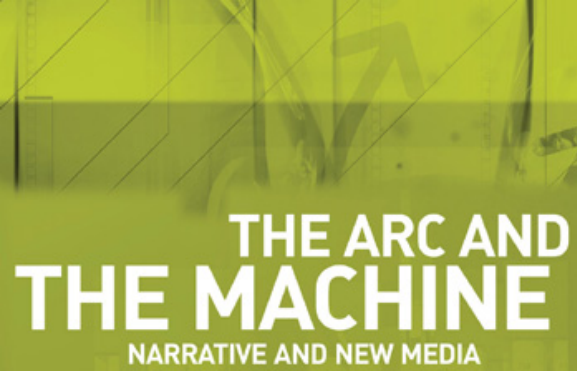

CAROLINE BASSETT

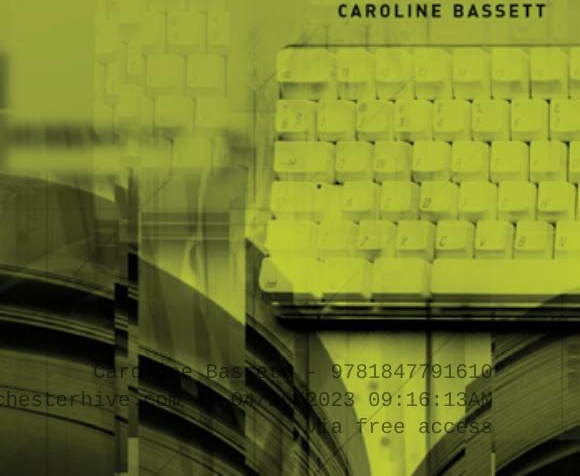




\section{The arc and the machine}

\section{MANCHESTER 1824}

Manchester University Press 
Caroline Bassett - 9781847791610

Downloaded from manchesterhive.com at 04/26/2023 09:16:13AM via free access 


\section{The arc and the machine Narrative and new media}

\section{Caroline Bassett}

Manchester University Press

Manchester and New York

distributed exclusively in the USA by Palgrave 
Copyright (C) Caroline Bassett 2007

The right of Caroline Bassett to be identified as the author of this work has been asserted by her in accordance with the Copyright, Designs and Patents Act 1988.

Published by Manchester University Press Oxford Road, Manchester M13 9NR, UK and Room 400, 175 Fifth Avenue, New York, NY 10010, USA www.manchesteruniversitypress.co.uk

Distributed exclusively in the USA by

Palgrave, 175 Fifth Avenue, New York, NY 10010, USA

Distributed exclusively in Canada by

UBC Press, University of British Columbia, 2029 West Mall, Vancouver, BC, Canada V6T 1Z2

British Library Cataloguing-in-Publication Data

A catalogue record for this book is available from the British Library

Library of Congress Cataloging-in-Publication Data applied for

ISBN 9780719073427 hardback

First published 2007

$16151413121110090807 \quad 10987654321$

Typeset

by Florence Production Ltd, Stoodleigh, Devon

Printed in Great Britain

by The Cromwell Press Ltd, Trowbridge 